(except in transverse bands) hyaline; tumid elevation large, with large brown spot. Wings longer than abdomen. Rostrum extending almost to end of rostral channel, the tip blackish. Legs testaceous. Nervures of elytra, carinæ, hood and paranota with a few erect spines.

Length, $3.51 \mathrm{~mm}$.; width, $2.10 \mathrm{~mm}$.

Holotype, female, and two paratypes, females, Santa Catalina Mts., Arizona, July 15, 1925, alt. 5000-6000 ft., collected on Vauquelinia californica (Torr.) Sarg. by A. A. Nichol. This is a very pretty and elegantly marked species. It is perhaps most closely allied to $C$. elegans Drake, differing in the larger tumid elevations, more constricted elytra and the different formed hood. The types are in the collection of the author.

\title{
OVIPOSITION OF THE ICHNEUMONID ITOPLECTIS CONQUISITOR (SAY) IN A LARVA OF PYRAUSTA NUBILALIS HUBN.
}

By Milton F. Crowell

During the summer of 1932 I was fortunate enough to see a female of Itoplectis conquisitor (Say) parasitize a larva of the European corn borer, Pyrausta nubilalis Hubn.

When first observed the female hymenopteron was running up and down over the upper part of a corn stalk, perhaps a foot below the tassel. Closer examination revealed that she was paying attention to a short section of the stalk just above a hole opening into a tunnel of the corn borer. She approached the hole, felt around it with her antennæ, then proceeded to explore with her antennæ the stalk just above it. After a short time, during which she felt over most of the area of the stalk for perhaps three inches above the hole, she stopped and thrust her ovipositor vertically into the corn stalk. She remained motionless for an estimated time of fifteen to twenty seconds. She then withdrew her ovipositor and flew away.

Cutting open the stalk I found a mature larva of Pyrausta nubilalis in the burrow, directly under the spot where Itoplectis conquisitor had thrust her ovipositor into it. 

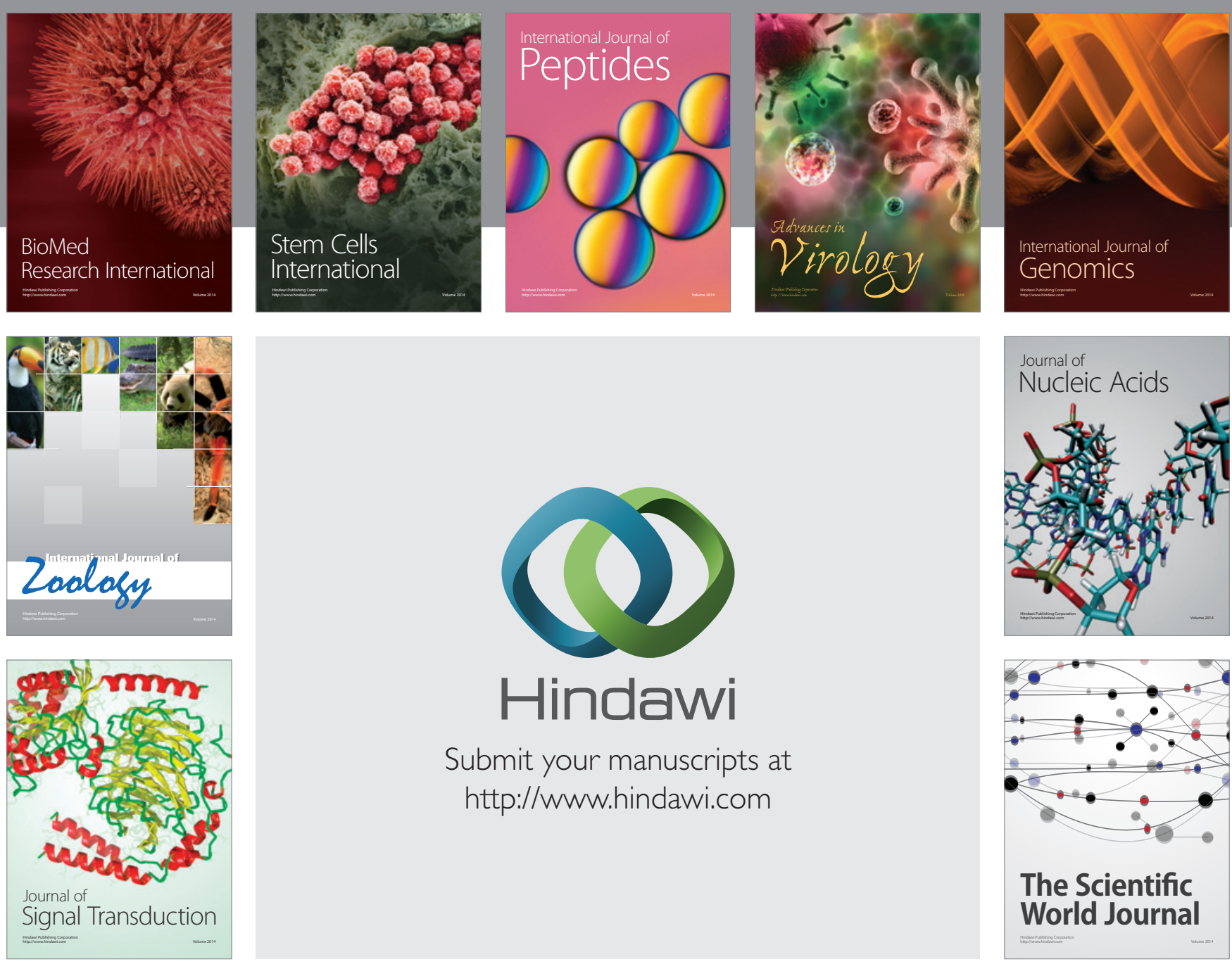

Submit your manuscripts at

http://www.hindawi.com
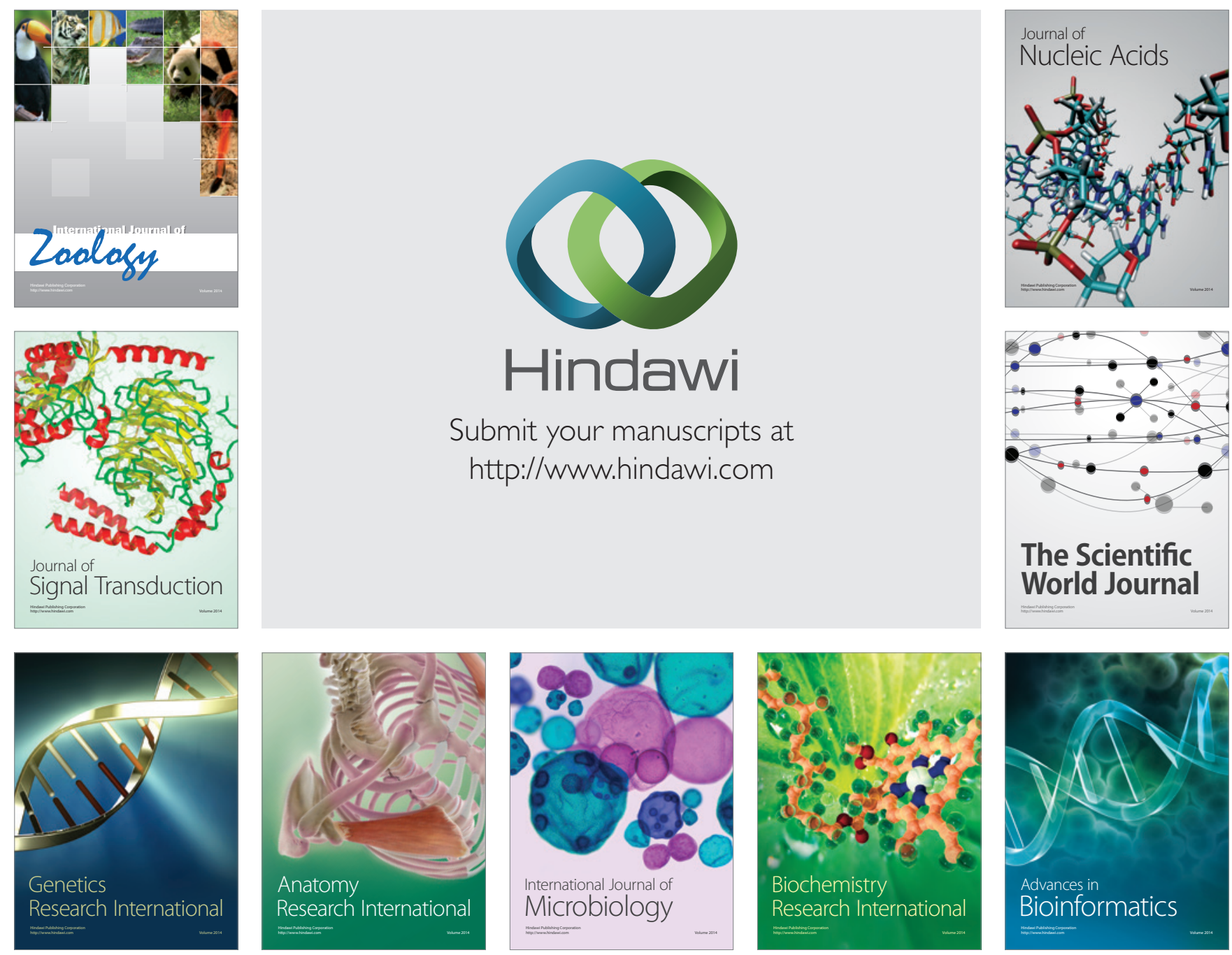

The Scientific World Journal
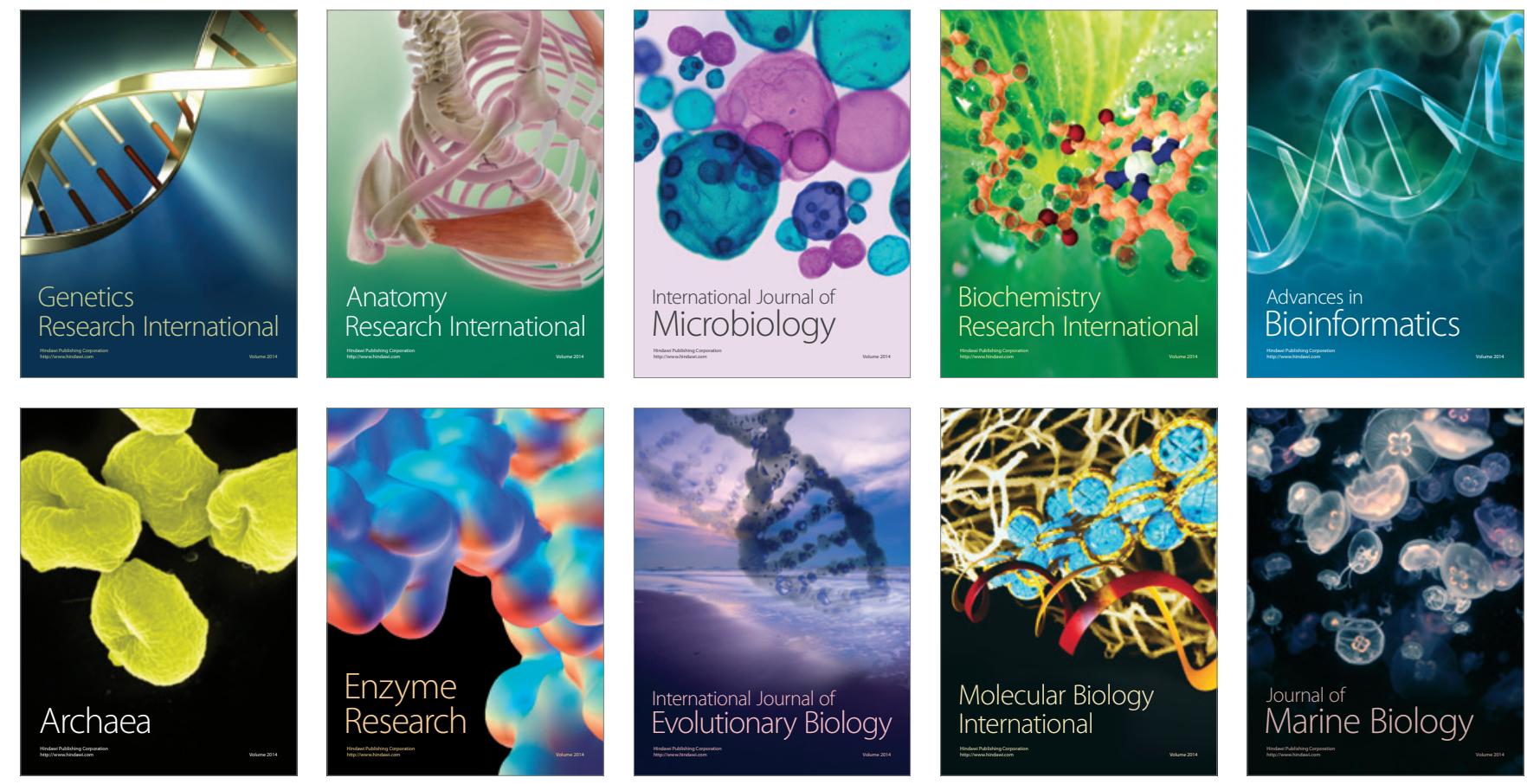